\title{
ANALISIS FAKTOR-FAKTOR SELF REGULATED LEARNING MAHASISWA SETELAH MENGGUNAKAN APLIKASI SISTEM PEMBELAJARAN ONLINE SPOT
}

\author{
Analysis of Self Regulated Learning Factors on Students after using \\ Integrated Online Learning System \\ Dini Meilani ${ }^{1}$, Dewi Cakrawati ${ }^{2}$, Yatti Sugiarti ${ }^{2}$ \\ 1,2 Program Studi Pendidikan Teknologi Agroindustri, \\ Fakultas Pendidikan Teknologi dan Kejuruan, Universitas Pendidikan Indonesia \\ E-mail: dewicakrawati@upi.edu
}

\begin{abstract}
ABSTRAK
Penelitian ini bertujuan untuk mengetahui faktor-faktor self regulated learning dominan pada mahasiswa Pendidikan Teknologi Agroindustri setelah menggunakan Sistem Pembelajaran On line Terpadu (SPOT) dan mengetahui kemampuan self regulated learning mahasiswa setelah menggunakan SPOT. Metode penelitian yang digunakan yaitu metode deskriptif kuantitatif. Instrument yang digunakan yaitu angket mengenai self regulated learning dan angket mengenai penggunaan SPOT. Aspek yang dinilai pada angket self regulated learning terdiri dari (A) goal setting and planning, (B) rehearsing and memorizing, (C) organizing and transforming, (D) self evaluating, (E) self consequence, (F) seeking social assistance, (G) environmental structuring, $(\mathrm{H})$ keeping records and monitoring, $(\mathrm{I})$ seeking information, $(\mathrm{J})$ reviewing records dan $(\mathrm{K})$ other (help seeking). Teknik pengambilan sampel menggunakan teknik purposive sampling sebanyak 102 responden. Hasil penelitian menunjukkan kebanyakan mahasiswa menggunakan SPOT karena dosen pengampu mata kuliah juga menggunakan spot dan mahasiswa menggunakan SPOT untuk mengunduh materi perkuliahan. Hasil penelitian menunjukkan bahwa aplikasi SPOT UPI dapat mengembangkan dua kemampuan dari self regulated learning yaitu organizing and transforming (pengorganisasian dan pentransformasian) sebesar $70,59 \%$. dan seeking information (mencari informasi) sebesar $70,59 \%$. Faktor perilaku merupakan faktor yang paling dominan pada mahasiswa Pendidikan Teknologi Agroindustri setelah menggunakan aplikasi SPOT UPI dengan persentase sebesar $65,33 \%$. Hasil penelitian menunjukkan bahwa aplikasi SPOT UPI dapat mendukung atau menunjang dua kemampuan self regulated learning yaitu organizing and transforming dan seeking information.
\end{abstract}

Kata Kunci: self regulated learning, sistem pembelajaran online, SPOT UPI

\begin{abstract}
The study aims was to determine the dominant factors of self-regulated learning on students of Study program Agroindustry Technology Education after using the Integrated Online Learning System (SPOT) and to know the ability of self-regulated learning in the Agroindustry Technology Education students after using SPOT. The research method used was descriptive quantitative method. Instruments used was questionnaire about selfregulated learning and questionnaire about the use of SPOT. Aspects assessed in self-regulated learning questionnaire consist of $(A)$ goal setting and planning, $(B)$ rehearsing and memorizing, (C) organizing and transforming, (D) self-evaluating, (E) self-consequence, (f) seeking social assistance, (G) environmental structuring, $(H)$ keeping records and monitoring, (I) seeking information, $(J)$ reviewing records and $(K)$ other (help seeking). Sampling technique using purposive sampling technique to 102 respondents. The result showed that most students use SPOT because lecturers also use spot and students use SPOT to download the course material. The results showed that SPOT UPI application can develop two capabilities of selfregulated learning that is organizing and transforming equal to $70,59 \%$ and seeking information (70.59\%). Behavioral factor was the most dominant factor in the students of Agroindustry Technology Education after using SPOT UPI application with the percentage of $65.33 \%$. The results showed that SPOT UPI application can support or support the two capabilities of self regulated learning which are organizing and transforming and seeking information.
\end{abstract}

Keywords : self regulated learning, online learning system, SPOT UPI 


\section{PENDAHULUAN}

Mahasiswa merupakan anggota sivitas akademik yang secara usia telah memasuki tahapan dewasa dan memiliki kesadaran diri dalam mengembangkan kemampuan di perguruan tinggi untuk menjadi tenaga ahli dan profesional (UU No. 12 Tahun 2012 Pasal 13 Ayat 1). Hal ini berarti mahasiswa seharusnya dapat belajar secara mandiri (Slavin, 2009). Woolfolk (2008) menambahkan mahasiswa sebagai individu yang telah memasuki tahapan dewasa dan memiliki kesadaran diri dalam mengembangkan kemampuannya, harus menjadi seorang pembejar berdasarkan pada regulasi diri (self regulated learning) sebagai self regulated learner.

Menurut Zimmerman (1999), Self regulated learning (SRL) adalah keterlibatan siswa secara aktif serta secara metakognitif, motivasional dan perilaku aktif dalam proses pembelajaran. Melalui self regulated learning, mahasiswa dapat menyusun strategi belajar sesuai tingkat kognisi dan motivasi (Schunk \& Zimmerman, 1998). Pengetahuan, motivasi dan disiplin diri juga merupakan faktor penting yang dapat mempengaruhi self regulated learning (Woolfolk, 2008). Pengetahuan yang dimaksudkan adalah pengetahuan tentang dirinya sendiri, materi, tugas, strategi untuk belajar dan konteks-konteks pembelajaran yang akan digunakan oleh mahasiswa. Oleh karena itu, dibutuhkan strategi yang tepat untuk mengembangkan self regulated learning pada diri mahasiswa.

Strategi pengembangan self regulated learning yaitu: self evaluating, organizing and transforming, goal-setting and planning, seeking information, keeping records and monitoring, environment structuring, self-consequeting, rehearsing and memorizing, seeking social assistance, reviewing records, other (Zimmerman dan Martinez, 1990). Seeking information, yang merupakan inisiatif diri dari mahasiswa dalam mencari informasi yang membantu dari sumber informasi non-sosial ketika sedang mengerjakan tugas, misalnya mahasiswa mencari informasi di perpustakaan dan internet. Pencarian informasi terkait sumber-sumber belajar tersebut dapat didukung dengan adanya teknologi informasi di dunia pendidikan tinggi yang yaitu e-learning.

Penyelenggaraan pendidikan jarak jauh pada pendidikan tinggi diatur oleh Kementerian Pendidikan dan Kebudayaan dalam permendikbud No. 109 tahun 2013 mengenai kebijakan terkait pembelajaran elektronik (e-learning). Tujuan e-learning adalah memberikan layanan pendidikan tinggi kepada kelompok masyarakat yang tidak dapat mengikuti pendidikan secara tatap muka dan memperluas akses serta mempermudah layanan pendidikan tinggi dalam pendidikan dan pembelajaran. Universitas Pendidikan Indonesia (UPI) memiliki fasilitas e-learning berupa aplikasi Sistem Pembelajaran Online Terpadu (SPOT) sebagai salah satu wujud pengembangan e-learning dalam proses pembelajarannya.

SPOT UPI adalah sebuah sistem aplikasi e-learning yang dibuat dan dikembangkan oleh direktorat TIK UPI yang didesain khusus untuk proses pembelajaran sesuai dengan kebutuhan sivitas UPI. Tujuan utama dari aplikasi SPOT UPI adalah sebagai penunjang atau pendukung pada proses pembelajaran, yang didalamnya memuat beberapa konten yang mendukung dalam proses pembelajaran seperti materi kuliah, tugas kuliah, catatan kuliah, evaluasi, kehadiran dan forum diskusi. SPOT UPI langsung terintegrasi kedalam Sistem Informasi Akademik (SIAK) UPI, sehingga aplikasi ini hanya bisa diakses dan digunakan oleh mahasiswa yang telah mengontrak mata kuliah di SIAK UPI. Penggunaan aplikasi SPOT UPI telah berjalan kurang lebih selama 5 tahun dan sudah banyak diimplementasikan di setiap jurusan/prodi yang ada di sivitas akademik UPI tak terkecuali program studi Pendidikan Teknologi Agroindutri.

Penggunaan e-learning pada SPOT UPI masih sebagai penunjang pembelajaran tatap muka, tetapi bisa menjadi pembelajaran baru yang lebih mandiri dan membuat mahasiswa bisa memunculkan self regulated learning dalam dirinya. Namun demikian, masih belum diketahui apakah dengan menggunakan SPOT, self regulated learning dalam diri mahasiswa dapat berkembang serta faktor-faktor self regulated learning mana yang dapat mengembangkan kemampuan self regulated learning mahasiswa setelah menggunakan aplikasi SPOT. Penelitian ini bertujuan untuk mengetahui faktor-faktor self regulated learning dominan pada mahasiswa Pendidikan Teknologi Agroindustri setelah menggunakan SPOT dan mengetahui kemampuan self regulated learning mahasiswa setelah menggunakan SPOT. 


\section{METODE}

\section{Desain Penelitian}

Jenis desain penelitian ini termasuk dalam penelitian deskriptif kuantitatif dengan menggunakan angket berskala likert dalam pengumpulan datanya yang disebarkan kepada mahasiswa Pendidikan Teknologi Agroindustri yang aktif menggunakan aplikasi SPOT UPI. Hasil pengumpulan data tersebut dianalisis dengan metode analisis deskriptif persentase. Analisis deskriptif persentase digunakan untuk mengetahui seberapa besar faktor-faktor yang dapat memunculkan kemampuan self regulated learning pada mahasiswa Pendidikan Teknologi Agroindustri setelah menggunakan aplikasi SPOT, yang kemudian dapat dilihat pula kemampuan self regulated learning mana yang dominan pada diri mahasiswa.

\section{Tempat dan Waktu Penelitian}

Penelitian ini dilakukan di Program Studi Pendidikan Teknologi Agroindustri Fakultas Pendidikan Teknologi dan Kejuruan Universitas Pendidikan Indonesia Jl. Dr. Setiabudhi No. 207, Bandung, Jawa Barat, 40154. Waktu penelitian dilakukan pada bulan Desember 2016.

\section{Sampel Penelitian}

Penentuan sampel dalam penelitian ini menggunakan teknik purposive sampling, dimana sampel diambil sesuai dengan tujuan penelitian yaitu mahasiswa yang aktif menggunakan dan memanfaatkan aplikasi SPOT UPI. Data dalam penelitian ini diperoleh dari responden mahasiswa Pendidikan Teknologi Agroindustri angkatan 2014 dan 2015 yang sudah menggunakan aplikasi SPOT UPI pada pembelajaran semester ganjil tahun 2016/2017.

\section{Teknik Pengumpulan Data}

Teknik pengumpulan data yang digunakan dalam penelitian ini adalah melalui penyebaran angket yang terdiri dari 2 angket yaitu angket tentang penggunaan aplikasi SPOT UPI dan angket tentang kemampuan self regulated learning mahasiswa Pendidikan Teknologi Agroindustri. Serta adapun data pengguna SPOT UPI dari direktorat TIK (Teknologi Informasi Komunikasi) UPI sebagai data penunjang pada penelitian ini. Validasi angket dlakukan dengan oleh judgement expert.

\section{Instrumen Penelitian}

\section{Angket}

Angket ini terdiri dari 2 angket yang digunakan untuk memperoleh data tentang pengguna aplikasi SPOT UPI dan self regulated learning mahasiswa Pendidikan Teknologi Agroindustri. Angket pertama berupa angket penggunaan aplikasi SPOT UPI yang berisi pertanyaan sebanyak 25 butir. Angket ini digunakan untuk mengetahui sejauh mana pengetahuan dan penggunaan aplikasi SPOT UPI oleh mahasiswa Pendidikan Teknologi Agroindustri. Angket kedua adalah angket tentang self regulated learning yang dihubungkan dengan penggunaan aplikasi SPOT UPI. Angket ini berisi pernyataan sebanyak 35 butir soal dengan skala likert $1-4$ (tidak pernah, kadangkadang, sering, selalu). Angket ini digunakan untuk mengetahui kemampuan self regulated learning mahasiswa yang dapat muncul setelah mahasiswa menggunakan aplikasi SPOT UPI, yang nantinya hasil angket tersebut diolah dan dianalisis. Kisi-kisi angket disajikan pada tabel 1.

\section{Data Pengguna SPOT UPI}

Data pengguna SPOT UPI didapat dari Direktorat TIK UPI yang menangani SPOT UPI dimana diperoleh jumlah atau persentase mahasiswa dan dosen Pendidikan Teknologi Agroindustri yang aktif dalam mengakses aplikasi SPOT UPI. Selanjutnya, data tersebut dapat menjadi pendukung dalam mendeskripsikan atau menganalisis hasil penelitian. 
Tabel 1. Kisi-kisi Angket Aplikasi SPOT UPI

\begin{tabular}{|c|c|c|}
\hline No. & Dimensi & Indikator \\
\hline 1 & Kesiapan & $\begin{array}{l}\text { 1. Kepemilikan alat atau fasilitas penggunaan aplikasi } \\
\text { 2. Mengatur waktu penggunaan aplikasi }\end{array}$ \\
\hline 2 & Kognisi & $\begin{array}{l}\text { 1. Mengetahui konsep aplikasi } \\
\text { 2. Mengetahui konten-konten pada aplikasi }\end{array}$ \\
\hline 3 & Implementasi & $\begin{array}{l}\text { 1. Mendeskripsikan fungsi konten pada aplikasi } \\
\text { 2. Ketepatan penggunaan aplikasi }\end{array}$ \\
\hline 4 & Kepuasan & 1. Kesan penggunaan aplikasi \\
\hline
\end{tabular}

Tabel 2. Kisi-kisi Angket Self Regulated Learning

\begin{tabular}{|c|c|c|}
\hline No. & Dimensi & Indikator \\
\hline \multirow{4}{*}{1} & \multirow{4}{*}{ Kognitif } & 1. Menetapkan Tujuan dan Perencanaan (Goal Setting and Planning) \\
\hline & & 2. Mengulang dan Mengingat (Rehearsing and Memorizing) \\
\hline & & 3. Mengorganisasi dan Mentransformasi (Organizing and Transforming) \\
\hline & & 4. Evaluasi Diri (Self Evaluating) \\
\hline \multirow{3}{*}{2} & \multirow{3}{*}{ Motivasi } & 1. Konsekuensi Diri (Self Consequence) \\
\hline & & 2. Mencari Bantuan Sosial (Seeking Social Assistance) \\
\hline & & 3. Mengatur Lingkungan (Environmental Structuring) \\
\hline \multirow{4}{*}{3} & \multirow{4}{*}{ Perilaku } & 1. Membuat dan Memeriksa Catatan (Keeping Records and Monitoring) \\
\hline & & 2. Mencari Informasi (Seeking Information) \\
\hline & & 3. Mereview Catatan dan Buku Teks (Reviewing Records) \\
\hline & & 4. Lainnya (Other/Help Seeking) \\
\hline
\end{tabular}

\section{Analisis Data}

Analisis data secara deskriptif melalui deskriptif persentase untuk mengetahui seberapa besar penerapan aplikasi SPOT UPI dalam pengembangan self regulated learning mahasiswa pendidikan teknologi agroindustri. Langkah-langkah yang ditempuh dalam penggunaan teknik analisis ini menurut Ghazali (2011) adalah sebagai berikut:

a. Mengumpulkan angket yang telah diisi responden dengan memeriksa kelengkapan.

b. Mengubah skor kualitatif menjadi skor kuantitatif berdasarkan skala likert yang digunakan.

c. Membuat tabulasi skor.

d. Memasukkan dalam rumus deskriptif persentase yaitu:

Keterangan:

$$
P=\frac{n}{N} \times 100 \%
$$

$$
\begin{array}{ll}
\mathrm{P} & =\text { Persentase variabel } \\
\mathrm{n} & =\text { Nilai yang diperoleh } \\
\mathrm{N} & =\text { Jumlah seluruh nilai }
\end{array}
$$

e. Membuat tabel rujukan dengan cara sebagai berikut:

1) Menetapkan persentase tertinggi

$$
\begin{aligned}
& =\frac{\text { Skor maksimal }}{\text { Skor ideal }} \times 100 \% \\
& =\frac{4}{4} \times 100 \%=100 \%
\end{aligned}
$$

2) Menetapkan persentase terendah

$$
\begin{aligned}
& =\frac{\text { Skor minimal }}{\text { Skor ideal }} \times 100 \% \\
& =\frac{1}{4} \times 100 \%=25 \%
\end{aligned}
$$

3) Menetapkan rentangan persentase

$=$ Persentase tertinggi - Persentase terendah

$=100 \%-25 \%=75 \%$

4) Menetapkan kelas interval

$=$ Rentangan persentase : Skala interval

$=75 \%: 4=18,75 \%$ 


\section{HASIL DAN PEMBAHASAN}

Berdasarkan hasil wawancara dengan penanggung jawab program aplikasi SPOT UPI dari Direktorat Teknologi Informasi dan Komunikasi (TIK), diketahui bahwa, Sistem Pembelajaran Online Terpadu (SPOT) Universitas Pendidikan Indonesia merupakan aplikasi e-learning dalam konteks learning management system yang dirancang untuk memfasilitasi pembelajaran dengan modus jarak jauh, mandiri dan fleksibel. Sistem Pembelajaran Online Terpadu UPI berfungsi sebagai perangkat pendukung dari media pembelajaran langsung yang digunakan dalam perkuliahan tatap muka UPI. Dengan demikian, mahasiswa perlu memenuhi beberapa aspek untuk melaksanakan sistem pembelajaran dengan menggunakan aplikasi SPOT UPI yaitu kesiapan, kognisi, implementasi dan kepuasan. Persentase aspek penggunaan SPOT mahasisa Prodi Pendidikan Teknologi Agroindustri disajikan pada Tabel 1.

Tabel 1. Persentase Aspek Penggunaan Aplikasi SPOT UPI Mahasiswa Pendidikan Teknologi Agroindustri

\begin{tabular}{lcc}
\hline Aspek Penggunaan Aplikasi SPOT UPI & Persentase (\%) & Kriteria \\
\hline Kesiapan & 83.09 & Sangat Tinggi \\
Kognisi & 92.48 & Sangat Tinggi \\
Implementasi & 61.48 & Cukup \\
Kepuasan & 96.57 & Sangat Tinggi \\
\hline
\end{tabular}

Melihat tingginya hasil yang diperoleh dari setiap aspek tersebut, maka dengan adanya aplikasi SPOT UPI ini diharapkan dapat membantu mengembangkan kemampuan self regulated learning mahasiswa Pendidikan Teknologi Agroindustri. Berdasarkan aspek kesiapan tersebut menunjukkan bahwa hampir seluruh mahasiswa memiliki alat dan fasilitas untuk dapat menggunakan aplikasi SPOT UPI. Mahasiswa juga sudah mengatur waktu penggunaan aplikasi ini dengan baik. Kemudian dari aspek kognisi juga dapat diketahui bahwa mahasiswa Pendidikan Teknologi Agroindustri telah mengetahui dan memahami konsep serta konten-konten pada aplikasi SPOT UPI. Pada aspek implementasi juga dapat diketahui bahwa mahasiswa dapat mendeskripsikan fungsi aplikasi SPOT UPI. Hasil angket menunjukkan mahasiswa menggunakan SPOT untuk memperoleh materi kuliah sementara fitur mengunggah tugas jarang digunakan karena hal ini berhubungan dengan penugasan dari dosen pengampu.

\section{Faktor dan Kemampuan Self Regulated Learning}

Faktor yang dianalisis pada penelitian ini yaitu kognisi, motivasi dan perilaku seperti yang dikembangkan oleh Wolters et. al. (2003). Indikator yang termasuk pada faktor kognisi yaitu goal setting and planning, rehearsing and memorizing, organizing and transforming dan self evaluating. Kemudian indikator yang termasuk pada faktor motivasi yaitu self consequence, seeking social assistance dan environmental structuring. Sedangkan indikator yang termasuk pada faktor perilaku yaitu keeping records and monitoring, seeking information, reviewing records dan other/help seeking. Persentase ketiga faktor kemampuan self regulated learning yang tersaji pada Gambar 2.

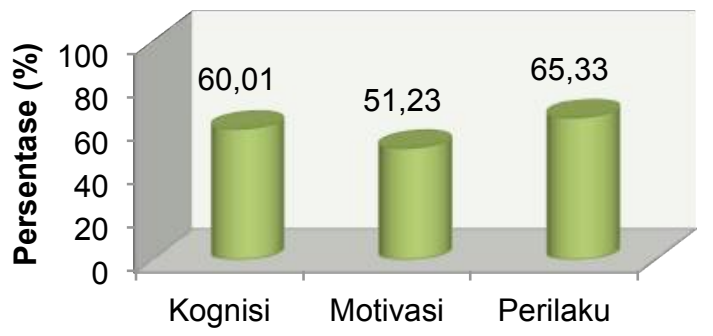

Gambar 2. Persentase Faktor - faktor Kemampuan SRL Mahasiswa Pendidikan Teknologi Agroindustri Setelah Menggunakan SPOT 
Berdasarkan ketiga faktor tersebut, maka pada penelitian ini ada 11 indikator untuk mengukur kemampuan self regulated learning mahasiswa Pendidikan Teknologi Agroindustri yang diambil dari strategi milik Zimmerman (1990) seperti tersaji pada Tabel 2.

Tabel 2. Persentase dan Kategori Kemampuan Self Regulated Learning Mahasiswa Pendidikan Teknologi Agroindustri Setelah Menggunakan Aplikasi SPOT UPI

\begin{tabular}{clcc}
\hline No. & \multicolumn{1}{c}{ Indikator Kemampuan SRL } & Persentase (\%) & Kategori \\
\hline A & Goal Setting and Planning & 69.83 & Tinggi \\
B & Rehearsing and Memorizing & 56.86 & Cukup \\
C & Organizing and Transforming & 70.59 & Tinggi \\
D & Self Evaluating & 68.38 & Tinggi \\
E & Self Consequence & 57.54 & Cukup \\
F & Seeking Social Assistance & 42.30 & Rendah \\
G & Environmental Structuring & 60.91 & Cukup \\
H & Keeping Records and Monitoring & 59.56 & Cukup \\
I & Seeking Information & 70.59 & Tinggi \\
J & Reviewing Records & 66.09 & Tinggi \\
K & Other (Help Seeking). & 64.71 & Cukup \\
\hline
\end{tabular}

Tabel 2. menunjukkan ada 2 indikator kemampuan SRL mahasiswa dengan persentase dan kategori paling tinggi yaitu kemampuan Organizing and Tranforming (mengorganisasi dan mentransformasi) $(70,59 \%)$ dan Seekin Information (mencari informasi) sebesar $(70,59 \%)$, sedangkan indikator kemampuan self regulated learning mahasiswa dengan persentase paling rendah adalah pada mencari bantuan sosial $(42,30 \%)$.

Selanjutnya dilakukan analisis pada setiap butir angket dari masing-masing indikator. Persentase dan kategori pada setiap butir angket kemampuan SRL mahasiswa (Tabel 3).

Tabel 3. Faktor Dominan dalam Indikator Kemampuan Self Regulated Learning Mahasiswa PTAG Setelah Menggunakan Aplikasi SPOT UPI

\begin{tabular}{|c|c|c|c|c|c|}
\hline No & Indikator & Deskripsi Kemampuan SRL & No Soal & $\%$ & Kategori \\
\hline A & $\begin{array}{l}\text { Goal Setting and } \\
\text { Planning }\end{array}$ & $\begin{array}{lll}\text { Mengatur } \quad \text { waktu } & \text { dalam } \\
\text { penyelesaian tujuan } & \end{array}$ & 3 & 89.22 & $\begin{array}{c}\text { Sangat } \\
\text { Tinggi }\end{array}$ \\
\hline B & $\begin{array}{l}\text { Rehearsing and } \\
\text { Memorizing }\end{array}$ & $\begin{array}{l}\text { Mengingat materi dengan belajar } \\
\text { sendiri }\end{array}$ & 13 & 58.82 & Cukup \\
\hline C & $\begin{array}{l}\text { Organizing and } \\
\text { Transforming }\end{array}$ & $\begin{array}{l}\text { Menyusun kembali materi yang } \\
\text { sudah didapat }\end{array}$ & 10 & 81.86 & $\begin{array}{l}\text { Sangat } \\
\text { Tinggi }\end{array}$ \\
\hline D & Self Evaluating & $\begin{array}{l}\text { Mengevaluasi kualitas/kemajuan } \\
\text { dari tugas }\end{array}$ & 21 & 77.45 & Tinggi \\
\hline$E$ & Self Consequnce & $\begin{array}{l}\text { Menyusun dan memprediksi } \\
\text { keuntungan yang akan diperoleh }\end{array}$ & 9 & 78.43 & Tinggi \\
\hline $\mathrm{F}$ & $\begin{array}{l}\text { Seeking Social } \\
\text { Assistance }\end{array}$ & $\begin{array}{l}\text { Mempelajari dan mendiskusikan } \\
\text { materi yang telah didapat bersama } \\
\text { teman }\end{array}$ & 14 & 55.88 & Cukup \\
\hline G & $\begin{array}{l}\text { Environmental } \\
\text { Structuring }\end{array}$ & $\begin{array}{l}\text { Mengatur dan memilih lingkungan } \\
\text { belajar yang nyaman }\end{array}$ & 29 & 67.16 & Tinggi \\
\hline $\mathrm{H}$ & $\begin{array}{l}\text { Keeping Records } \\
\text { and Monitoring }\end{array}$ & $\begin{array}{l}\text { Memantau keberadaan materi } \\
\text { perkuliahan baru yang diberikan } \\
\text { dosen }\end{array}$ & 27 & 66.67 & Tinggi \\
\hline I & $\begin{array}{l}\text { Seeking } \\
\text { Information }\end{array}$ & $\begin{array}{lll}\text { Mencari } & \text { sendiri } & \text { referensi } \\
\text { perkuliahan } & & \end{array}$ & 7 & 78.19 & Tinggi \\
\hline J & $\begin{array}{l}\text { Reviewing } \\
\text { Records }\end{array}$ & $\begin{array}{l}\text { Mempelajari kembali materi-materi } \\
\text { perkuliahan untuk persiapan ujian }\end{array}$ & 33 & 75.98 & Tinggi \\
\hline K & $\begin{array}{l}\text { Other } \\
\text { Seeking). }\end{array}$ & $\begin{array}{l}\text { Perilaku belajar yang diinisiasi oleh } \\
\text { orang lain (dosen) }\end{array}$ & 20 & 70.59 & Cukup \\
\hline
\end{tabular}




\section{A. Goal Setting And Planning}

Goal setting and planning merupakan usaha mengatur tujuan dan rencana untuk mengurutkan prioritas, serta mengatur waktu dalam menyelesaikan tugas (Zimmerman, 1990). Goal setting and planning juga merupakan inisiatif diri dari mahasiswa dalam menentukan tujuan pembelajaran dan perencanaan waktu dan aktivitas penyelesaian tujuan (Hariseno, 2012). Berdasarkan Tabel 4.2, mahasiswa Pendidikan Teknologi Agroindustri yang telah menggunakan aplikasi SPOT UPI memiliki kemampuan goal setting and planning yang tinggi dengan persentase $69,90 \%$. Pengaturan tujuan dalam belajar merupakan langkah awal dalam proses terciptanya self regulated learning pada diri seseorang seperti yang dijelaskan Wolters (2003). Kemampuan mengatur tujuan dan rencana belajar merupakan kemampuan awal yang sangat penting dimiliki oleh seorang self regulated learner. Adapun aspek yang paling dominan dalam indikator adalah pengaturan waktu dalam menyelesaikan tugas misalnya ketika dosen menugaskan mahasiswa untuk mengirim tugas melalui aplikasi SPOT maka ditetapkan batas maksimal dan mahasiswa tidak dapat mengunggah tugas setelah batas waktu yang ditetapkan. Hal tersebut menunjukkan adanya peran orang lain yaitu dosen dan teman kuliah, serta lingkungan yang berupa sistem yaitu SPOT UPI. Hal tersebut merupakan pengaruh eksternal yang mempengaruhi self regulated learning pada diri mahasiswa, karena self regulated learning tidak hanya ditentukan oleh proses pribadi saja, tetapi juga dipengaruhi oleh lingkungan dan perilaku secara timbal balik (Zimmerman, 1989). Aspek ini dapat menumbuhkan sikap disiplin mahasiswa, dimana disiplin diri atau volition (kemauan diri) merupakan faktor penting lain yang dapat mempengaruhi self regulated learning (Woolfolk, 2008). Borkowski dan Thorp (1996) menyatakan bahwa banyak peneliti sepakat bahwa aspek yang paling mendasar dari self regulated learning adalah keterfokusan pada tujuan. Self regulated learning adalah usaha aktif dan mandiri mahasiswa dengan memantau, mengatur dan mengontrol kognisi, motivasi dan perilaku yang diorientasikan atau diarahkan pada tujuan belajar (Kurniawan, 2013). Maka dengan demikian, mahasiswa terlebih dahulu harus memiliki tujuan yang tetap sehingga dapat melakukan usaha-usaha untuk mengembangkan kemampuan self regulated learning yang ada dalam diri mahasiswa.

\section{B. Rehearsing And Memorizing}

Rehearsing and memorizing ini sebagai inisiatif diri mahasiswa dalam berusaha mengingat materi dengan cara berlatih atau mempelajari materi secara berulang-ulang sampai dapat mengingat atau menghafalnya secara bersama teman ataupun belajar sendiri (Zimmerman, 1990). Tabel 2 menunjukkan mahasiswa Pendidikan Teknologi Agroindustri yang telah menggunakan aplikasi SPOT UPI memiliki kemampuan rehearsing and memorizing pada persentase $56,86 \%$. Aspek kemampuan rehearsing and memorizing yang paling dominan pada indikator ini adalah mengingat materi dengan belajar sendiri $(58,82 \%)$, karena aplikasi SPOT digunakan untuk memperoleh materi perkuliahan.

Kemampuan self regulated learning berupa rehearsing and memorizing pada mahasiswa Pendidikan Teknologi Agroindustri setelah menggunakan aplikasi SPOT UPI ini mendapatkan hasil yang rendah, karena meskipun terdapat fitur diskusi tetapi jarang pada apilkasi ini tetapi fitur tersebut jarang digunakan. Mahasiswa dan dosen lebih memilih menggunakan aplikasi lain yang terdapat pada telepon genggam karena alasan kepraktisan dan kemudahan.

\section{Organizing and Transforming}

Organizing and transforming atau pengorganisasian dan pentransformasian adalah usaha menyusun kembali materi yang sudah diterima dan ditulis kembali agar mudah untuk dipahami (Zimmerman, 1990). Tabel 2 menunjukkan mahasiswa Pendidikan Teknologi Agroindustri yang telah menggunakan aplikasi SPOT UPI memiliki kemampuan organizing and transforming dengan persentase $70,59 \%$. Indikator ini merupakan salah satu indikator paling dominan muncul pada mahasiswa Pendidikan Teknologi Agroindustri setelah menggunakan aplikasi SPOT UPI dengan aspek dominan yaitu menyusun kembali materi yang sudah didapat dari SPOT UPI $(81,86 \%)$.

Mahasiswa yang memiliki self regulated learning dapat diamati dari sikat berupa tindakan atau perbuatan yang mengarah pada tercapainya tujuan belajar (Setyanto, 2014). Karakteristik mahasiswa yang memiliki self regulated learning tinggi diantaranya adalah mahasiswa akan terbiasa dalam melakukan pengulangan, elaborasi dan pengorganisasian dalam mengikuti proses 
pembelajaran (Montalvo \& Tores, 2004). Selain menyusun kembali materi-materi yang sudah didapatkan dari aplikasi SPOT UPI secara teratur, ada aspek lain juga yang ada pada indikator kemampuan organizing and transforming ini adalah menulis kembali materi yang didapat dari aplikasi SPOT UPI. Merangkum dan menulis kembali hal-hal penting pada materi pembelajan merupakan salah satu cara dari aspek kognitif untuk memaksimalkan kinerja otak agar dapat berfikir dan menerima pembelajaran dengan baik (Wolters et al., 2003).

\section{Self Evaluating}

Self evaluating adalah usaha mengevaluasi kualitas tugas atau kemajuan dari tugas dan belajar yang sudah dilaksanakan (Zimmerman, 1990). Self evaluating juga merupakan inisiatif diri mahasiswa dalam mengevaluasi kemajuan atau peninjauan kembali atas usaha maupun hasil usaha yang dilakukan dalam mengerjakan suatu tugas akademik (Hariseno, 2012). Kemampuan mengevaluasi ini penting dimiliki oleh mahasiswa dalam menumbuhkan self regulated learning, karena dapat melatih inisiatif diri untuk lebih teliti ketika melakukan proses pembelajaran sehingga mahasiswa dapat mengatur kognisi dirinya dengan baik. Dalam proses pembelajaran, seseorang yang memiliki self regulated learning dapat membangun tujuan-tujuan belajar, mencoba memonitor, meregulasi dan mengontrol kognisi, motivasi dan perilakunya untuk mengontrol tujuan-tujuan yang telah dibuat (Valle et al., 2008).

Tabel 2 menunjukkan mahasiswa Pendidikan Teknologi Agroindustri yang telah menggunakan aplikasi SPOT UPI memiliki kemampuan self evaluating yang tinggi dengan persentase 68,38 aspek yang paling dominan adalah mengevaluasi kualitas atau kemajuan dari tugas perkuliahan $(77,45 \%)$. Self regulated learning adalah proses pembelajaran individu yang dilakukan secara mandiri dan terencana dalam menyusus serangkaian aktifitas belajar sesuai dengan tujuan yang sudah ditetapkan sebelumnya, yang kemudian setelah tujuan tercapai, maka dilanjutkan dengan mengevaluasi hasil untuk dapat diperbaiki dan ditingkatkan agar mencapai hasil yang optimal (Setyanto, 2014). Zimmerman (1999) menyebutkan bahwa siswa yang menggunakan metode self regulated learning memiliki kesadaran terhadap hasil kinerjanya. Aspek yang paling mendasar dari self regulated learning adalah keterfokusan pada tujuan, maka mengevaluasi adalah cara yang paling baik untuk mencapai tujuannya (Latipah, 2010).

\section{E. Self Consequence}

Self Consequence adalah kemampuan mahasiswa untuk menyusun dan memprediksi hadiah atau hukuman atas kesuksesan atau kegagalan yang dialami dalam kegiatan belajar (Zimmerman, 1990). Self Consequence ini penting karena bertujuan membuat mahasiswa tetap bertahan dan lebih semangat dalam belajar serta menuntaskan target belajar karena ada imbalan atau kesenangan yang akan diberikan oleh diri sendiri. Tabel 4.2 menunjukkan mahasiswa Pendidikan Teknologi Agroindustri yang telah menggunakan aplikasi SPOT UPI memiliki kemampuan self consequence dengan persentase $57,54 \%$ dengan aspek paling dominan adalah menyusun dan memprediksi keuntungan yang akan diperoleh jika menggunakan aplikasi SPOT UPI (78,43\%). Mahasiswa dalam perkembangannya berada pada kategori remaja akhir yang berada dalam rentang $18-21$ tahun. Pada tahap ini, perkembangan individu ditandai dengan adanya pencarian identitas diri, adanya pengaruh dari lingkungan, serta mulai dapat membuat keputusan untuk dirinya sendiri (Abu, 2005).

Aspek lain yang dominan pada indicator sel consequence adalah harapan mendapatkan nilai tambahan dari dosen dengan persentase 40,20. Aspek ini memperlihatkan suatu konsekuensi berupa hadiah yang dipikirkan mahasiswa yaitu bahwa jika mahasiswa sering membuka dan menggunakan aplikasi SPOT UPI maka dirinya akan mendapatkan nilai tambahan dari dosen mereka. Namun, aspek ini mendapatkan persentase yang rendah karena ternyata kemampuan self consequence ini merupakan penyediaan konsekuensi dengan membayangkan imbalan atau kesenangan yang akan diberikan oleh diri sendiri bukan orang lain. Pada aspek ini, keuntungan atau imbalan yang akan didapat mahasiswa berasal dari pihak lain yaitu dosen, artinya keuntungan atau imbalan tersebut bukan datang dari diri mahasiswa sendiri. Berbeda dengan aspek yang sebelumnya dibahas dimana keuntungan yang mahasiswa dapatkan memang berasal dari dirinya sendiri sehingga menciptakan motivasi dalam diri mahasiswa untuk dapat mengatur atau mengelola dirinya dalam pencapaian tujuan belajarnya.

Motivasi merupakan inti dari pengelolaan diri dalam belajar (self regulated learning), dimana melalui motivasi siswa mau mengambil tindakan dan tanggung jawab atas kegiatan belajar yang dia lakukan (Smith, 2001). Seperti yang didefinisikan Baumert et al. (2002), bahwa self regulated learning didefinisikan sebagai bentuk belajar individual dengan bergantung pada motivasi belajar. 


\section{F. Seeking Social Assistance}

Seeking social assistance adalah usaha mencari atau meminta bantuan dari teman sebaya, dosen dan orang lain apabila menemui kesulitan belajar (Zimmerman, 1990). Kemampuan seeking social assistance ini merupakan inisiatif diri mahasiswa dalam mendapatkan bantuan dari teman, dosen atau orang lain ketika mengalami kesulitan belajar yang dapat mempengaruhi kegiatan proses pembelajarannya. Tabel 2 menunjukkan mahasiswa Pendidikan Teknologi Agroindustri yang telah menggunakan aplikasi SPOT UPI memiliki kemampuan seeking social assistance dengan persentase $42,30 \%$ dengan aspek kemampuan paling dominan adalah mendiskusikan materi perkuliahan yang didapat dari SPOT UPI bersama teman kelas $(55,88 \%)$.

Adapun aspek lain pada indikator seeking social assistance ini yang tidak dominan dan termasuk pada kategori rendah adalah mendiskusikan materi dengan dosen di "forum diskusi" pada SPOT UPI (34,56\%). Mahasiswa Pendidikan Teknologi Agroindustri ternyata tidak terlalu memanfaatkan konten "forum diskusi" yang ada pada aplikasi SPOT UPI ini dengan optimal. Hal ini mungkin dikarenakan proses diskusi secara langsung lebih efektif dan efisien dibanding dengan berdiskusi melalui konten "forum diskusi" pada aplikasi SPOT UPI. Walaupun demikian, mahasiswa Pendidikan Teknologi Agroindustri telah menerapkan interaksi sosial seperti berdiskusi baik dengan teman kelas maupun dengan guru dalam proses pembelajarannya.Interaksi sosial dengan teman kelas/kuliah dapat mempengaruhi strategi belajar pada pengembangan self regulated learning mahasiswa (Effeney, 2013). Teman sebaya dan kelompok berpotensi untuk mendorong motivasi lebih dalam suatu pembelajaran. Dengan seringnya diskusi yang dilakukan antara kelompok yang terdiri dari teman kelas tersebut maka dapat meningkatkan faktor kemampuan self regulated learning pada mahasiswa (Jones et al., 2008).

\section{G. Environmental Structuring}

Environmental structuring atau mengatur lingkungan adalah usaha untuk mengatur lingkungan belajar dengan tujuan membuat belajar menjadi lebih mudah dan nyaman (Zimmerman, 1990). Tabel 4.2 menunjukkan mahasiswa Pendidikan Teknologi Agroindustri yang telah menggunakan aplikasi SPOT UPI memiliki kemampuan evironmental structuring yang cukup dengan persentase $60,91 \%$ dengan aspek paling dominan adalah mengatur dan memilih lingkungan atau tempat yang nyaman untuk menggunakan aplikasi SPOT UPI $(67,16 \%)$. Mahasiswa Pendidikan Teknologi Agroindustri lebih sering menggunakan aplikasi SPOT UPI ketika sedang berada di rumah. Jika mahasiswa memiliki kemampuan mencari dan memilih lingkungan (evironmental structuring) yang baik, artinya mahasiswa dapat menghindari gangguan ketika proses belajar, dan menyusun lingkungan yang nyaman untuk belajar, maka usaha untuk belajar akan bisa berjalan dengan optimal. Dengan tetap terjaganya proses belajar, maka tujuan belajar akan tercapai. Oleh karena itu, kemampuan mencari dan memilih lingkungan (evironmental structuring) penting dimiliki oleh seorang self regulated learner karena menurut teori social kognitif, self regulated learning tidak hanya ditentukan oleh proses pribadi, tetapi juga dipengaruhi oleh lingkungan dan perilaku secara timbale balik (Zimmerman, 1989).

\section{H. Keeping Records And Monitoring}

Keeping records and monitoring atau membuat dan memeriksa catatan adalah usaha yang dilakukan untuk merekam dan memantau peristiwa atau hasil pembelajaran yang diterima pada saat proses pembelajaran (Zimmerman, 1990). Keeping records and monitoring merupakan inisiatif diri mahasiswa dalam berusaha untuk merekam atau memiliki catatan atas suatu hasil pembelajaran. Tabel 2 menunjukkan mahasiswa Pendidikan Teknologi Agroindustri yang telah menggunakan aplikasi SPOT UPI memiliki kemampuan keeping records and monitoring yang cukup dengan persentase $59,56 \%$ dengan aspek paling dominan adalah memantau keberadaan materi perkuliahan baru yang dibagikan dosen di SPOT UPI $(66,67 \%)$.

\section{Seeking Information}

Seeking information atau mencari informasi adalah usaha untuk mendapatkan informasi sesuai dengan tugas yang dikerjakan dari sumber referensi lainnya (Zimmerman, 1990). Seeking information juga merupakan inisiatif diri mahasiswa dalam mencari informasi yang membantu atau berguna dari sumber informasi non-sosial ketika sedang mengerjakan tugas. Tabel 2 menunjukkan mahasiswa Pendidikan Teknologi Agroindustri yang telah menggunakan aplikasi SPOT UPI memiliki kemampuan seeking information sebesar 70,59\% dan menjadi indikator atau kemampuan yang paling dominan. Hal ini dikarenakan mahasiswa menggunakan aplikasi SPOT untuk mencari sumber belajar. 
Berkaitan dengan kemampuan individu dalam mengenali sumber daya yang terdapat pada lingkungan, Zimmerman (dalam Smith, 2002) menggunakan istilah 'resourcefullness' yang mengacu pada kemampuan untuk mengontrol lingkungan fisik disekitarnya dalam hal membatasi distraksi yang mengganggu kegiatan belajar, dan secara sukses mencari dan menggunakan referensi dan keahlian yang diperlukan untuk menguasai apa yang dipelajari.

\section{J. Reviewing Records}

Reviewing records atau memeriksa catatan dan buku teks adalah usaha membaca kembali catatan untuk mempelajari materi yang sudah didapatkan untuk belajar atau persiapan ujian. Reviewing records merupakan inisiatif diri mahasiswa dalam berusaha untuk membaca ulang soal ujian, catatan atau buku teks untuk mempersiapkan diri dalam menghadapi ujian yang akan dihadapi. Tabel 2 menunjukkan mahasiswa Pendidikan Teknologi Agroindustri yang telah menggunakan aplikasi SPOT UPI memiliki kemampuan keeping records yang tinggi dengan persentase sebesar $66,09 \%$ dengan aspek paling adalah mempelajari kembali materi-materi dari SPOT UPI perkuliahan untuk persiapan ujian $(75,98 \%)$, Dalam proses pembelajaran, ujian merupakan kegiatan atau tahap dalam pembelajaran yang bertujuan untuk melihat, menilai serta mengevaluasi kemampuan dan hasil proses pembelajaran yang telah dilakukan oleh pembelajar. Maka,untuk mendapatkan hasil yang maksimal pembelajar khususnya mahasiswa tentu akan melakukan strategi atau usaha untuk mendapatkan hasil maksimal tersebut. Dengan melakukan reviewing records ini, maka mahasiswa akan lebih siap dan percaya diri dalam menghadapi ujian, sehingga menciptakan pemikan bahwa peluang untuk mendapatkan hasil yang optimal sangat besar serta sangat tujuan belajar dalam diri seorang self regulated learner dapat dicapai.

\section{K. Other (Help Seeking)}

Other (help seeking) adalah perilaku yang diinisiasi oleh orang lain seperti teman, guru, orang tua ataupun orang lain. Misalnya mahasiswa mengerjakan tugas atas instruksi dosen, atau contoh lain inisiatif diri untuk mencontoh cara belajar yang diterapkan oleh orang lain tersebut. Meskipun strategi ini bukan merupakan inisiatif dari diri sendiri, namun sebenarnya keputusan untuk mau mengikuti atau tidak arahan dari orang lain terletak pada mahasiswa itu sendiri. Tabel 2 menunjukkan mahasiswa Pendidikan Teknologi Agroindustri yang telah menggunakan aplikasi SPOT UPI memiliki kemampuan other (help seeking) sebesar $64,71 \%$ dengan aspek paling dominan adalah perilaku belajar yang diinisiasi oleh orang lain $(70,59 \%)$, yaitu mahasiswa Pendidikan Teknologi Agroindustri menggunakan aplikasi SPOT UPI jika ada instruksi dari dosen. Sedangkan untuk aspek lain pada kemampuan other (help seeking) ini adalah mahasiswa mencoba meniru cara belajar teman yang rajin dan berprestasi mendapatkan persentase sebesar $58,82 \%$.

Perkembangan kemampuan belajar seseorang bisa datang dari tindakan orang lain yaitu berupa instruksi dan bimbingan atau arahan dari guru atau dosen (Bremiller et al., 1998). Instruksi dan bimbingan tersebut dapat mendorong pembelajar untuk dapat lebih menguasai suatu pembelajaran. Pembelajar memperoleh kemampuan dan strategi self regulated learning dengan cepat dari sumber sosial seperti mengamati atau mencontoh proses pembelajaran orang lain, deskripsi verbal dan bimbingan social secara timbal balik (Zimmerman dan Kitsantas, 2005). Hasil pada aspek ini menunjukkan bahwa mahasiswa Pendidikan Teknologi Agroindustri setelah menggunakan aplikasi SPOT UPI sudah cukup memiliki perilaku self regulated learner seperti yang dikemukakan teori diatas. Dengan adanya perilaku tersebut, diharapkan dapat memunculkan motivasi dalam diri mahasiswa sehingga dirinya tergerak untuk terus meningkatkan kualitas belajarnya, sehingga kemampuan self regulated learning mahasiswa dapat berkembang.

\section{SIMPULAN}

Faktor perilaku merupakan faktor self regulated learning yang paling dominan pada mahasiswa Pendidikan Teknologi Agroindustri setelah menggunakan aplikasi SPOT UPI dengan persentase sebesar $65,33 \%$. Ada dua kemampuan self regulated learning yang dominan pada mahasiswa Pendidikan Teknologi Agroindustri setelah menggunakan aplikasi SPOT UPI yaitu organization and transforming (pengorganisasian dan pentransformasian) dan seeking information (mencari informasi) sebesar $70,59 \%$. 


\section{DAFTAR PUSTAKA}

Abu, A., dan Munawar, S. 2005. Psikologi Perkembangan Edisi Revisi. Jakarta: PT Adi Mahastya Baumert, et al. 2002. Self Regulated Learning as Cross Cultural Concept. Berlin

Hariseno, H. 2012. Hubungan Antara Self-Regulated Learning, Tipe Kepribadian Artistik Menurut Holland Dan Prestasi Akademik Mahasiswa Jurusan Seni Musik. Skripsi: Tidak Diterbitkan.

Jones, M. H., Estell, D. B., \& Alexander, J. M. 2008. Friends, Classmates, And Self-Regulated Learning: Discussions With Peers Inside and Outside The Classroom. Metacognition and Learning, 3(1), 1-15.

Kurniawan, R. 2013. Hubungan Antara Self-Regulated Learningdengan Prokrastinasi Akademik Pada Mahasiswa Jurusan Psikologi Universitas Negeri Semarang. Skripsi: Tidak diterbitkan.

Latipah, E. 2010. Strategi Self Regulated Learning dan Prestasi Belajar: Kajian Meta Analisis. Jurnal Psikologi, 37 (1), 110-129.

Martinez-Ponz, M. 2002. A Social Cognitive View of Parental Influence on Student Academic Self regulation. Theory into Practice, 61, $126-131$

Montalvo, F. T., \& Torres, M. C. G. 2004. Self-Regulated Learning: Current and Future Directions. Electronics Journal of Research in Educational. No. 2 Vol. 1

Setyanto, G. G. 2014. Pengaruh Self-Regulated Learning Dan Pola Asuh Orang Tua Terhadap Prokrastinasi Akademik Mahasiswa Fakultas Ekonomi Universitas Negeri Yogyakarta. Skripsi: Tidak diterbitkan

Slavin. 2009. Educational Psychology. Engleewood Cliffs, New Jersey: Prentice-Hall, Inc.

Smith, P.A. 2001. Understanding Self Regulated Learning And Its Implications For Accounting Advocators And Research. Issue In Accounting Education, Vol. 16 No. 4: 663-667.

Wolters, C.A, Pintrich, P.R., \& Karabenick, S.A. 2003. Assessing Academic Self-Regulated Learning. Conference on Indicator of Positive Development: Child Trends, National Institute of Health.

Woolfolk. 2008. Educational Psychology. Active Learning Edition Tenth Edition. Boston: Allyn \& Bacn.

Zimmerman, B. J., \& Martinez-Ponz. 1986. Development of a structured interview for assessing student use of self regulated learning strategies. American Educational Research Journal, Vol. 23.

Zimmerman, B J. \& Martinez-Ponz, M. 1989. A Social Congnitive View Of Self- Regulated Academic Learning. Journal of Educational Physchology, Vol.81, No.3, Hal 329-339. Diakses melalui anitacrawley.net/articles/ZimmermanSocCog.pdf Pada 28 Mei 2014.

2001. Student Differences in Self Regulated Learning: Relating Grade, Sex, and Giftedness to Self Efficacy and Strategy Use. Journal of Education Psychology, 82 (1), 51 - 59

Zimmerman, B. J. 1990. Self Regulated Learning and Academic Achievement: An Overview. Educational Psychologist, Vol. 25, 3 - 17 1999. Acquiring Writing Revision Skill, Shifting From Process Goals To Outcome Self Regulatory Goals. Journal of Educational Psychology, Vol. 91 No. 2:241-250. . 2002. Becoming a Self Regulated Learner: An Overview. Theory into Practice, 41, 64-70.

Zimmerman, B. J., \& Kitsantas, A. 2005. The Hidden Dimension of Personal Competence: SelfRegulated Learning and Practice. In A. J. Elliot, C. S. Dweck, \& S. Carol (Eds.). Handbook of Competence and Motivation (Hal. 509-526). New York: Guilford Publication. 